\title{
Effects of primary stakeholders' support on expatriate adjustment and performance in
} Malaysia

\begin{abstract}
Globalisation encourages international companies to show interest in the growth of job mobility and relocations among employees. To meet global workforce demands, these companies are highly reliant on expatriates to manage their business operation abroad. This study examined the role of primary stakeholders' support such as organisations, host country nationals (HCNs) and spouses on expatriate adjustment and performance. Questionnaire survey data were collected from 112 expatriates in Malaysia and analysed using multiple hierarchical regression analysis. The results substantiated that perceived organisational support (POS) and $\mathrm{HCN}$ support were significant components in expatriate adjustment. The findings also revealed a positive relationship between expatriate adjustment and performance. Thus, multinational companies (MNCs) and human resource managers should provide expatriate relevant training and support to ensure a successful international assignment when he or she is sent abroad. Local employees could also be assigned to help expatriates mingle around in the host country.
\end{abstract}

Keyword: Expatriate adjustment; Support; Stakeholders; Expatriate performance; Malaysia 